\title{
EDWIN HOLLIS, MAMMALOGIST IN THE TOUCHWOOD HILLS, 1901-02.
}

\section{STUART HOUSTON, 863 University Drive, Saskatoon, Saskatchewan. S7N 0J8}

The contributions to Saskatchewan mammalogy of Dr. John Richardson at Carlton House and Cumberland House in the 1820 s are well known, commemorated as they are in the names of Richardson's and Franklin's Ground Squirrels. ${ }^{89}$ Less well known is that Will C. Colt ${ }^{6}$ collected the type specimen of the Least Weasel near Osler, Saskatchewan, on 15 July $1895 .^{1}$

Also unknown to most modern naturalists is an English mammalogist, Edwin Hollis, who collected in Saskatchewan's Touchwood Hills at the turn of the century. After some experience in the British Museum (Natural History), where he apparently learned to make study skins, Edwin Hollis came to Kutawa, a telegraph office and post office on the old Telegraph Trail between Qu'Appelle and Humboldt, and northeast of present Punnichy. ${ }^{2}$ Arriving on 7 July 1901, he stayed until 23 April 1902 as a guest of his relative, Joseph Hollis, who had arrived in 1884 to ranch on the northeast quarter of section 30 , township 28 , range 15 , west of the second meridian.?

Species collected by Edwin Hollis (using Banfield's modern names) and published in an annotated list in The Zoologist were: Red Bat, Hoary Bat, Ermine, Long-tailed Weasel, American Mink, Striped Skunk, American Badger, Red Fox, Coyote, Richardson's Ground Squirrel, Franklin's Ground Squirrel, Thirteen-lined Ground Squirrel, Least Chipmunk, Northern Pocket Gopher, Northern Grasshopper Mouse, Deer Mouse, Gapper's Red-backed Vole, Meadow Vole, Prairie Vole, Muskrat, Meadow Jumping Mouse, Snowshoe Hare, and an American Bison skull. ${ }^{45}$ It is of interest that in this Touchwood Hills parkland country, not one White-tailed Jackrabbit was collected.
On his return to England, Hollis gave a paper to a well-attended meeting of the Exeter College Field Club and Natural History Society, "Notes of a Naturalist in N.W. Canada." He also exhibited "a very nice collection of water-colour sketches of most of the animals dealt with, drawn by his wife." According to the Devon and Exeter Gazette of 16 January 1906, these illustrations "added much to the interest and lucidity of his

Announcement of Hollis' Exeter program.

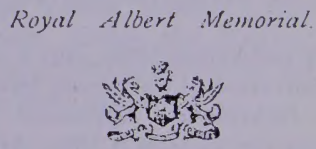

COLLEGE FIELd CLUb and hatural hISTORY SOSIETy

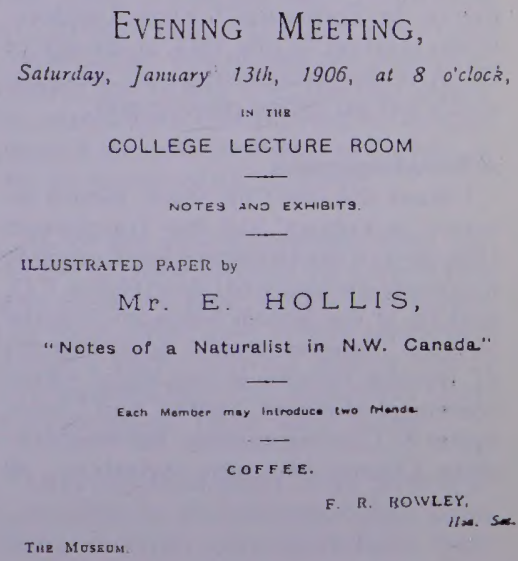


paper." The mammal collection, which Hollis presented to the British Museum (Natural History) in London, embraced 23 species, five of which were new to the museum, and ranged in size from the coyote to the shrew.

Hollis lived in Exeter between 1905 and 1908. He prepared many small mammal specimens, helped out at the Exeter Museum in a voluntary capacity and donated "a vast number of specimens to the museum." Other specimens of small mammals were donated by "Miss Hollis," who almost certainly had created the earlier water-colours. There is no record of his having married.

In January 1908, Hollis became curator and librarian at the Bucks [Buckinghamshire] Archaeological Society's Museum at Aylesbury and held this post for 33 years. He soon widened his interests, from mammalogy and taxidermy, to include local history and prehistory, especially ancient manuscripts and documents and tradesmen's tokens. He also did much educational work with school children, especially those evacuated to Exeter from London during the war.

Hollis published little, but a note on the occurrence of the Lesser Horseshoe Bat in Devonshire appeared in The Zoologist on 15 March 1907. An article on Devon tokens in the Transactions of the Devon Association, 77:177, 1945, speaks of him as Edwin Hollis, F.Z.S. (Fellow of the Zoological Society, London). Hollis died on 12 July 1941, at the age of $78 .^{3} \mathrm{~A}$ modest and retiring man, he apparently left no extant photograph.

\section{Acknowledgements}

I thank the late Cliff Shaw, whose interest in Kutawa and the Touchwood Hills post of the Hudson's Bay Company first made me aware of Edwin Hollis. P.D. Jenkins at the British Museum (Natural History), London; Kelvin Boot, Curator of Natural History at the Royal Albert Memorial Museum, Exeter; and Christopher N. Gowing, curator, Buckinghamshire County Museum, Aylesbury, all provided useful information about Edwin Hollis' correspondence, specimens and career. Darcy Hande at the Saskatchewan Archives kindly provided access to the original homestead files of Joseph Hollis.

${ }^{1}$ BANGS, OUTRAM. 1896. The weasels of eastern North America. Proc. Biological Soc. Washington 10:1-24.

2 COSSAR, MARY E., ed. 1955. Tales of the Touchwoods: From 1880-1953. Regina: Western Printers. $110 \mathrm{pp}$.

${ }^{3}$ ELAND, GEORGE. 1941. Memorial to Edwin Hollis. Records of Bucks, Chapter 14.

${ }^{4}$ HALL, E. RAYMOND. 1938. Mammals from Touchwood Hills, Saskatchewan. Can. FieldNat. 52: 108-109.

${ }^{5}$ HOLLIS, EDWIN. 1902. Collecting small mammals in N.W.T. Canada. The Zoologist, series 4, vol. 6: 294-299.

${ }^{6}$ HOUSTON, C.S. 1970 . Will C. Colt's migration records for Osler, Saskatchewan. Blue Jay 28:7-10.

7 PUNNICHY AND DISTRICTS HISTORY BOOK COMMITTEE. 1983. Between the Touchwoods: a history of Punnichy and districts. Punnichy and Districts History Book Committee, Punnichy, SK.

${ }^{8}$ RICHARDSON, J. 1829. Fauna BorealiAmericana, or the zoology of the northern parts of British America. Part First: The mammals. London: John Murray.

${ }^{9}$ SABINE, J. 1822. Account of the marmots of North America hitherto known, with notices and descriptions of three new species. Trans. Linnean Soc. 13:19-31. 